\title{
Hubungan Pengetahuan Terhadap Perilaku Ibu Dalam Penyimpanan Asi Perah Di Posyandu Mon Singet Desa Kajhu Kabupaten Aceh Besar Tahun 2019
}

\section{The Relationship of Knowledge to Mother's Behavior in the Storage of Breast Milk in Mon Singet Posyandu, Kajhu Village, Aceh Besar District 2019}

\author{
Eva Rosdiana ${ }^{1}$, Chairanisa Anwar ${ }^{2}$, Ulfa Husna Dhirah ${ }^{3}$, Marniati $^{4}$ \\ Universitas Ubudiyah Indonesia
}

eva_rosdiana@uui.ac.id, chaira.anwar@uui.ac.id,ulfahusna@uui.ac.id,marniati@uui.ac.id

\begin{abstract}
ABSTRAK
Penyimpanan ASI Perah yang baik dan benar masih menjadi hal yang tabu di masyarakat, sehingga ASI yang telah di perah tidak terjaga kualitasnya, bahkan sebagian ibu membuang ASI yang telah di perah karena takut kualitas ASI menjadi tidak baik. Hasil wawancara dengan 7 orang ibu yang memberikan ASI 4 di anataranya melakukan praktik ASI Perah namun hanya 2 orang yang tahu bagaimana penyimpanan ASI perah yang benar. Tujuan penelitian ini adalah untuk mengetahui bagaimana perilaku ibu dalam penyimpanan ASI Perah di Psoyandu Mon Singet Desa Kajhu Kabupaten Aceh Besar. Penelitian ini menggunakan metode analitik dengan pendekatan Cross Sectional. Jumlah sampel di ambil secara accidental sampling yang berjumlah 30 responden. Penelitian di laksanakan pada tanggal 10 januari 2020. Uji statistik yang digunakan adalah Chi Square Test dengan taraf kepercayaan 95\%. Hasil penelitian menunjukan bahwa tidak ada hubungan antara pengetahuan dengan perilaku ibu dalam penyimpanan ASI Perah dengan nilai $\mathrm{p}=0,651 \quad(\mathrm{P}>0,05)$. Diharapkan kepada petugas kesehatan untuk dapat mensosialisasi tentang penyimpanan ASI Perah yang baik dan benar melalui poster-poster atau pendidikan kesehatan secara langsung khusunya kepada Ibu yang sedang menyusui.
\end{abstract}

Kata Kunci : Pengetahuan, Penyimpanan ASI Perah

\section{ABSTRACT}

Storage of good and true milk is still a taboo in the community, so the quality of milk that has been milked is not maintained, even some mothers discard milk that has been milked for fear of the quality of breast milk being not good. The results of interviews with 7 mothers who gave 4 ASI among them did the practice of breastfeeding, but only 2 people knew how to properly store breast milk. The purpose of this study was to determine how the mother's behavior in storing breast milk in Psoyandu Mon Singet, Kajhu Village, Aceh Besar District. This research uses analytic method with Cross Sectional approach. The number of samples taken by accidental sampling, amounting to 30 respondents. The study was conducted on 10 January 2020. The statistical test used was the Chi Square Test with a 95\% confidence level. The results showed 
Journal of Healthcare Technology and Medicine Vol. 6 No. 1 April 2020

Universitas Ubudiyah Indonesia

e-ISSN : 2615-109X

that there was no relationship between knowledge and maternal behavior in storing breast milk with a value of $p=0.651$ ( $P>0.05$ ). It is expected that health workers can be able to socialize about the storage of good and right breastmilk through posters or health education directly especially to mothers who are breastfeeding.

Keywords: Knowledge, Breast Milk Storage

\section{PENDAHULUAN}

ASI merupakan makanan ideal yang dapat mengoptimalkan proses tumbuh kembang bagi bayi. Asi memiliki kandungan dan jumlah zat gizi yang sesuai dengan kebutuhan tubuh bayi (Fikawati, dkk, 2015). Sehingga ASI di nobatkan sebagai satu-satunya makanan terbaik bagi bayi karena di dalam ASI sudah mengandung segala zat gizi sesuai dengan kebutuhan bayi.

Keputusan WHO untuk memberikan ASI eksklusif 6 bulan dan MP-ASI setelahnya dengan tetap memberikan ASI hingga 2 tahun telah diadopsi oleh pemerintah Indonesia. Hal tersebut diatur melalui Kepmenkes RI No. 450/Menkes/SK/ IV/2004 dengan menetapkan target pemberian ASI eksklusif 6 bulan sebesar 80\% (Kemenkes RI, 2004)

Menurut data WHO (2015) hanya 44\% bayi yang lahir di dunia yang mendapat ASI dalam satu jam pertamasejak lahir bahkan masih sedikt bayi di bawah usia enam bulan di susui secara eklusif. Cakupan pemberian ASI eklusif di Afrika tengah sebanyak 25\%, Amerika latin dan karibia sebanyak 32\%, Asia Timut sebanyak 30\%. Secara keseluruhan, kurang dari 40\% anak dibawah usia enam bulan di beri ASI Eklusif.

Pemberian ASI Eklusif di Indonesia belum mencapai 100\%. Berdasarkan data dari Kemenkes RI (2018), cakupan pemberian ASI Eklusif di Indonesia tahun 2018 adalah sebanyak 37,3\%. Daerah dengan cakupan presentasi tertinggi adalah Bangka Belitung yaitu 56,7\% dan daerah dengan cakupan terendah adalah Nusa Tenggara Barat (NTB) yaitu sebesar 20,3\%.

Berdasarkan data dari Dinas Kesehatan Aceh (2017), cakupan pemberian ASI Eklusif pada bayi usia 0-6 bulan di Aceh sebesar 55\%. Angka ini mengalami peningkatan dari tahun sebelumnya. Daerah dengan cakupan tertinggi adalah Pidie jaya, sedangkan daerah dengan cakupan terendah adalah kota sabang.

Rendahnya cakupan pemberian ASI Eklusif pada bayi tentunya di sebabkan oleh berbagai faktor. Salah satunya adalah ibu yang harus kembali bekerja setelah selesai masa cuti. Ibu yang bekerja biasanya akan meninggalkan bayinya dalam beberapa waktu yang menyebabkan intensitas menyusui menjadi berkurang. Ibu bekerja akan menitipkan bayinya 
Journal of Healthcare Technology and Medicine Vol. 6 No. 1 April 2020

Universitas Ubudiyah Indonesia

e-ISSN : 2615-109X

kepada penjaga, dan sering kali memberikan makanan tambahan seperti susu formula, makanan cair atau makanan padat lainnya.

Pekerjaan sebenarnya bukanlah suatu alasan sebagai penghambat pemberian ASI bagi

ibu. Meski berprofesi sebagai wanita karir, ibu tetap bisa memberikan ASI secara eklusif bagi bayinya, ASI dapat diperah kemudan di simpan di dalam kulkas atau freezer, dan dapat diberikan kembali kapanpun bayi membutuhkan. Sehingga meskipun ibu bekerja bayi tetap mendapatkan ASI tanpa tambahan makanan apapun.

Untuk memerah ASI tentunya ibu harus memiliki pengetahuan tentang cara memerah ASI dan menyimpan ASI yang baik dan benar, sehingga komposisi ASI tetap terjaga dan tidak rusak. Selain pengetahuan ibu juga harus memiliki sifat yang positif sehingga ibu mau memerah ASI untuk bayinya dan menyimpannya dengan cara yang tepat dan benar. Hal ini sesuai dengan teori yang di sampaikan oleh Wulandari, dkk (2013) yaitu terbentuknya suatu perilaku baru, terutama pada orang dewasa biasanya dimulai dari ranah kognitif, dimana subjek tahu terlebih dahulu akan adanya stimulus yang menimbulkan pengetahuan baru. Pengetahuan tersebut akan menimbulkan respon batin dalam bentuk sikap tertentu. Stimulus atau objek yang telah diketahui dan disadari tersebut akan menimbulkan respon yang lebih jauh lagi berupa tindakan.

\section{METODE PENELITIAN}

Penelitian ini merupakan penelitian yang bersifat Analitik, dengan menggunakan pendekatan Cross Sectional. Populasi yang di gunakan adalah ibu yang memiliki anak usia 0-24 bulan. Teknik pengambilan sampel di lakukan dengan accidental sampling, sehingga jumlah sampel yang di dapatkan adalah 30 responden. Penelitian ini di lakukan di Posyandu Mon Singet Desa Kajhu pada tanggal 10 Januari 2020.

\section{ANALISA DATA}

Analisa data dilakukan dengan analisa univariat dan Analisa bivariate. Analisis univariat dilakukan terhadap tiap variabel dari hasil penelitian. Sedangkan analisa bivariate dilakukan untuk melihat hubungan dua variabel menggunakan uji chi-square test. dengan taraf signifikasi 95\% ( $\mathrm{p}<0,05)$. Sehingga dapat diketahui ada tidaknya pengaruh yang bermakna secara statistik dengan menggunakan program komputer 
Journal of Healthcare Technology and Medicine Vol. 6 No. 1 April 2020

Universitas Ubudiyah Indonesia

e-ISSN : 2615-109X

\section{HASIL DAN PEMBAHASAN \\ Analisa Univariat}

\section{Tabel 5.1}

Distribusi Frekuensi Variabel Pada Ibu Yang Memiliki Bayi Berumur 0-24 Bulan Di Posyandu Mon Singet Desa Kajhu Kabupaten Aceh Besar

\begin{tabular}{llcc}
\hline No & \multicolumn{1}{c}{ Variabel Penelitian } & Frekuensi (f) & Persentase (\%) \\
\hline 1 & Pengetahuan & & \\
& Kurang & 3 & 10,0 \\
& Cukup & 13 & 43,3 \\
& Baik & 14 & 46,7 \\
\hline 2 & Perilaku & & \\
& Buruk & 25 & 83,3 \\
& Baik & 5 & 16,7 \\
\hline
\end{tabular}

Berdasarkan tabel 5.1 menunjukkan bahwa variabel pengetahuan mayoritas pada katagori baik yaitu 14 responden $(46, \%)$. Variabel perilaku mayoritas pada kategori buruk yaitu 25 responden $(83,3 \%)$.

Analisa Bivariat

Hubungan Pengetahuan dengan Perilaku Ibu dalam Penyimpanan ASI Perah di Posyandu Mon Singet Desa Kajhu Kecamatan Baitussalam Aceh Besar

\begin{tabular}{lccccccc}
\hline & \multicolumn{4}{c}{ Perilaku Ibu } & Total & p value \\
\cline { 2 - 6 } \multicolumn{1}{c}{ Pengetahuan } & $\mathrm{f}$ & $\%$ & $\mathrm{f}$ & $\%$ & $\mathrm{~F}$ & $\%$ & \\
\cline { 2 - 7 } & 3 & 100,0 & 0 & 0,0 & 3 & 100 & 0,651 \\
Kurang & 10 & 76,9 & 3 & 23,1 & 13 & 100 & \\
Cukup & 12 & 85,7 & 2 & 14,3 & 14 & 100 & \\
Baik & 25 & 83,3 & 5 & 16,7 & 30 & 100 & \\
Total & & & & & & & \\
\hline
\end{tabular}

Berdasarkan Tabel 5.2 menunjukkan bahwa dari 3 responden yang berpengetahuan kurang mayoritas memiliki perilaku yang buruk yaitu sebanyak 3 responden (100\%), dari 13 responden yang berpengetahuan cukup mayoritas berperilaku buruk sebanyak 10 responden (76,9\%) dan dari 14 responden yang berpengetahuan baik mayoritas berperilaku buruk sebanyak 12 responden $(85,7 \%)$

Hasil uji statistik diperoleh $p$ value $=0,651 \mathrm{p}(>0,05)$. Sehingga dapat disimpulkan bahwa tidak ada hubungan antara pengetahuan ibu dengan perilaku ibu dalam penyimpanan ASI Perah di Posyandu Mon Singet Desa Kajhu Aceh Besar Tahun 2020. 
Journal of Healthcare Technology and Medicine Vol. 6 No. 1 April 2020

Universitas Ubudiyah Indonesia

e-ISSN : 2615-109X

Berdasarkan Tabel 5.2 menunjukkan bahwa dari 3 responden yang berpengetahuan kurang mayoritas memiliki perilaku yang buruk yaitu sebanyak 3 responden (100\%), dari 13 responden yang berpengetahuan cukup mayoritas berperilaku buruk sebanyak 10 responden $(76,9 \%)$ dan dari 14 responden yang berpengetahuan baik mayoritas berperilaku buruk sebanyak 12 responden $(85,7 \%)$. Hasil uji statistic di peroleh nilai $\mathrm{p}=0,651$ yang berarti tidak ada hubungan antara pengetahuan dengan perilaku ibu dalam penyimpanan ASI Perah.

Hasil penelitian ini tidak sejalan dengan teori yang menyatakan bahwa pengetahuan memegang peranan penting dalam penentuan perilaku yang utuh karena pengetahuan akan membentuk kepercayaan yang selanjutnya dalam mempersepsikan kenyataan, memberikan dasar bagi pengambilan keputusan dan menentukan perilaku terhadap objek tertentu (Noyoatmodjo, 2013).

Dalam penelitian ini dapat di lihat bahwa mayoritas ibu memiliki pengetahuan yang baik tentang penyimpanan ASI Perah namun mereka berperilaku negatif dalam penyimpanan ASI Perah. Berdasarkan fakta penelitian di lapangan peneliti menemukan bahwa 46,7\% ibu mengetahui tentang penyimpanan ASI Perah yang baik dan 43,3\% memiliki pengetahuan yang cukup namun mereka ragu tentang kandungan ASI setelah di simpan di dalam kulkas apalagi untuk waktu yang lama.

Perilaku seseorang di tentukan oleh dua factor yaitu faktor dari dalam diri individu tersebut dan juga faktor dari luar yaitu lingkungan. Faktor dari dalam diri salah satunya adalah pengetahuan. Orang yang memiliki pengetahuan belum tentu akan membawa dirinya untuk berperilaku baik, karena masih ada faktor lingkungan yang mempengaruhinya, dan menurut Notoatmodjo (2010) faktor lingkungan merupakan faktor dominan yang mempengaruhi perilaku seseorang. Sehingga meskipun responden dalam penelitian ini mayoritas mengetahui tentang penyimpanan ASI Perah namun tidak memiliki perilaku yang baik dalam praktik penyimpanan ASI Perah.

\section{KESIMPULAN}

Berdasarkan hasil penelitian yang di lakukan di Posyandu Mon Singet Desa Kajhu terhadap Ibu yang memiliki anak Usia 0-24 bulan maka dapat di simpulkan bahwa:

1. Pengetahuan Ibu tentang penyimpanan ASI Perah paling banyak adalah pada katgeori baik namun hanya $46,7 \%$ 
Journal of Healthcare Technology and Medicine Vol. 6 No. 1 April 2020

Universitas Ubudiyah Indonesia

e-ISSN : 2615-109X

2. Perilaku ibu dalam penyimpanan ASI Perah paling banyak pada kategori buruk yaitu $83,3 \%$

3. Tidak ada hubungan antara pengetahuan dengan perilaku ibu dalam penyimpanan ASI Perah dengan nilai $\mathrm{p}=0,651(\mathrm{P}>0,05)$

\section{SARAN}

Diharapkan kepada petugas kesehatan khusunya petugas Puskesmas dan Posyandu agar dapat memberikan penyuluhan dan pendidikan kesehatan yang lebih baik lagi kepada ibu sejak akhir kehamilan hingga masa menyusui tentang penyimpanan ASI Perah yang baik, sehingga jumlah ibu yang memiliki pengetahuan yang baik tentang ASI Perah lebih banyak dan ibu yang sudah memiliki pengetahuan yang baik tetapi memiliki perilaku yang buruk dapat merubah perilakunya menjadi lebih baik.

\section{DAFTAR PUSTAKA}

Azwar, Saifuddin (2012). Sikap Manusia: Teori dan Pengukurannya. Yogyakarta: Liberty Azzisya, S (2010). Sukses Menyusui Meski Bekerja. Jakarta : Gema Insane

Kemenkes RI (2014). Keputusan Menteri Kesehatan Republik Indonesia No 450/Menkes/SK IV/2004 tentang pemberian Air Susu Ibu (ASI) secara eksklusif pada bayi di Indonesia. Jakarta: Kementerian Kesehatan RI; 2004.

Kemenkes RI (2013). Riset Kesehatan Dasar (RISKESDAS) Tahun 2013. Jakarta: Badan Penelitian dan Pengembangan Kesehatan Kementerian Kesehatan RI; 2013

Notoatmodjo (2010). Ilmu perilaku Kesehatan. Jakarta : Rineka Cipta

Notoatmodjo, Soekidjo (2012). Promosi kesehatan dan Perilaku Kesehatan. Jakarta : Rineka cipta

Notoatmodjo (2013) Promosi Kesehatan Global. Jakarta : Rineka Cipta

Riksani, R. (2012). Keajaiban ASI (Air Susu Ibu). Jakarta: Dunia Sehat

Walgito, Bimo. (2010). Bimbingan dan Konseling Study \& Karir. Yogyakarta : Andi

Wawan \&Dewi M (2010) Teori dan Pengukuran Sikap dan Perilaku Manusa. Surabaya : Numed

Wulandari, A, Meikawati, W dan Kumalasari, N (2013). Hubungan Tingkat Pengetahuan Dan Sikap Terhadap Air Susu Ibu Perah (Asip) Dengan Praktik Pemberian Asip Pada Ibu Bekerja Di Kelurahan Tandang Kecamatan Tembalang Kota Semarang. Vol 12. No. 2 . jurnal kebidanan unimus

Yohmi, Elisabeth (2019). Penyimpanan ASI Perah.IDAI.http://www.idai.or.id/artikel/ klinik/ asi/ penyimpanan-asi-perah. Diakses tanggal 01 desember 2019

Wawan \&Dewi M (2010) Teori dan Pengukuran Sikap dan Perilaku Manusa. Surabaya : Numed 